Equilibrium : Jurnal Pendidikan

Vol. X. Issu 1. Januari-April 2022
Prodi Pendidikan Sosiologi

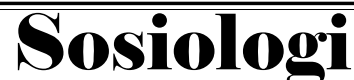

http://journal.unismuh.ac.id/index.php/equilibrium

\title{
Be KePo (Bioetanol Ketela Pohon) Inovasi Pemberdayaan Ekonomi Masyarakat dan Solusi Sumber Energi Alternatif Terbaharukan
}

\author{
Muhammad Alhada Fuadilah Habib ${ }^{1}$ Wahyu Nita Kurrotaa'yun Nuriski ${ }^{2}$ Rizal Zamzami ${ }^{3}$ \\ ${ }^{1}$ Universitas Islam Negeri Sayyid Ali Rahmatullah Tulungagung \\ Email: habibhada@gmail.com \\ ${ }^{2}$ Universitas Islam Negeri Sayyid Ali Rahmatullah Tulungagung \\ Email: nitawahyu758@gmail.com \\ ${ }^{3}$ Universitas Islam Negeri Sayyid Ali Rahmatullah Tulungagung \\ Email: rizalzamzami@iain-tulungagung.ac.id
}

\begin{abstract}
Fossil energy sources are non-renewable energy sources. Meanwhile, until now, the main source of energy used by the people of Indonesia comes from fossils. Currently, Indonesia is in an energy crisis because it relies heavily on fossil fuels, especially oil, which burdens the state budget and drains the country's foreign exchange. This is because oil reserves in Indonesia are running low and they must import petroleum needs from abroad, therefore, Indonesia must have the ability (knowledge and technology) combined with local wisdom (wisdom) to overcome this energy problem. From several alternative renewable energy sources, one of the most potential to be developed in Indonesia is bioethanol technology. The development of bioethanol energy sources is very suitable considering that this energy source comes from vegetable materials which are natural resources that are easily renewable and widely available in Indonesia. Blitar Regency is an area in East Java Province whose soil is classified as fertile and has the potential to be used as a producer of raw materials for making bioethanol. Until now, most of the people in Blitar Regency work in the agricultural sector and quite a lot of them fall into the category of poor people. This condition is because agricultural products are sold raw (without being processed) and have a relatively low selling price, while the costs for maintaining agricultural crops are quite expensive. This condition encourages innovation in community empowerment in the field of bioethanol technology to solve the problem of scarcity of fossil energy sources as well as a solution to improve the economy of the people in Blitar Regency.
\end{abstract}

Keywords : Community Empowerment; Bioethanol Technology; Alternative Energy Sources; Community Economic Improvement.

Abstrak. Sumber energi yang berasal dari fosil merupakan sumber energi yang tidak terbaharukan. Sementara itu sampai saat ini, sumber energi utama yang digunakan oleh masyarakat Indonesia berasal dari fosil. Saat ini Indonesia berada dalam krisis energi karena sangat bergantung pada bahan bakar fosil terutama minyak bumi yang memberatkan $A P B N$ dan menguras devisa negara. Hal ini dikarenakan cadangan minyak bumi di Indonesia kian menipis dan harus mengimpor kebutuhan minyak bumi dari luar negeri, oleh sebab itu, Indonesia harus memiliki kemampuan (knowledge and technology) yang dipadukan dengan kearifan local (wisdom) untuk mengatasi permasalahan energi ini. Dari beberapa pilihan sumber energi alternatif terbaharukan, salah satu yang paling potensial dikembangkan di Indonesia adalah dengan teknologi bioetanol. Pengembangan sumber energi bioetanol ini sangat cocok dilakukan mengingat sumber energi ini berasal dari bahan nabati yang merupakan sumber daya alam yang mudah diperbaharui dan banyak tersedia di Indonesia. Kabupaten Blitar merupakan sebuah kawasan di Provinsi Jawa Timur yang tanahnya tergolong subur dan sangat potensial digunakan sebagai penghasil bahan baku pembuatan bioetanol. Sampai saat ini sebagian besar masyarakat di Kabupaten Blitar bekerja di sektor pertanian dan masih cukup banyak yang masuk dalam kategori masyarakat miskin. Kondisi ini dikarenakan produk hasil pertanian dijual mentah (tanpa diolah) dan memiliki harga jual yang relatif rendah, sementara itu biaya untuk perawatan tanaman pertanian cukup mahal. Kondisi ini mendorong inovasi pemberdayaan masyarakat di bidang teknologi bioetanol untuk memecahkan persoalan kelangkaan sumber energi fosil sekaligus sebagai solusi untuk meningkatkan perekonomian masyarakat di Kabupaten Blitar.

Kata Kunci : Pemberdayaan Masyarakat; Teknologi Bioetanol; Sumber Energi Alternatif; Peningkatan Ekonomi Masyarakat. 


\section{PENDAHULUAN}

Seperti yang telah diketahui bersama bahwa, sumber energi yang berasal dari fosil seperti minyak bumi, batu bara dan gas alam merupakan sumber energi yang tidak terbaharukan. Dikatakan tidak terbaharukan karena terbentuk dalam kurun waktu jutaan tahun dari sisa-sisa organik tumbuhan dan hewan. Dengan demikian, bahan bakar minyak yang berasal dari fosil ini terbentuk dalam kurun waktu yang sangat lama. Sumber energi ini dikatakan tidak terbaharukan, sebab jika cadangan bahan bakar fosil habis, butuh waktu jutaan tahun untuk mendapatkannya kembali (Kuncahyo, Fathallah, \& Sanuri, 2013).

Dewasa ini bahan bakar minyak yang berasal dari fosil mengalami eksploitasi yang sangat besar untuk memenuhi permintaan masyarakat, terutama untuk kebutuhan transportasi dan industri. Kebutuhan masyarakat akan bahan bakar fosil yang semakin meningkat ini, menimbulkan masalah yang cukup serius. Masalah ini terjadi karena ketersediaan sumber bahan bakar fosil semakin menipis sementara cadangan bahan bakar fosil tiap tahunnya terus mengalami penurunan. Diprediksi hanya akan bertahan sampai akhir abad 21 untuk minyak bumi, pertengahan abad 22 (sekitar tahun 2165) untuk gas alam, dan sekitar tahun 2230 untuk batubara (Hudaya, 2016).

Sampai saat ini, sumber energi utama di Indonesia untuk menggerakan alat transportasi, alatalat indurtri, pertanian, dan rumah tangga, masih menggunakan bahan bakar minyak yang berasal dari fosil. Ketergantungan terhadap energi fosil, terutama minyak bumi, di negeri ini masih sangat tinggi. Penggunaan bahan kabar yang berasal dari fosil mencapai $96 \%$ dari seluruh alternetif sumber energi yang ada, dengan rincian $48 \%$ minyak bumi, $30 \%$ batu bara, dan $18 \%$ gas alam (Purnomo, et al., 2020). Sebenarnya Indonesia sudah mulai menggunakan berbagai alternatif sumber energi yang terbaharukan seperti bioenergy dan pemanfaatan sinar matahari, namun demikian penggunaan energi terbaharukan ini masih sangat minim, yaitu hanya mencapai $8 \%$ jika dibandingkan dengan penggunaan bahan bakar yang berasal dari fosil (Hudaya, 2016).

Dalam beberapa tahun terakhir ini, kapasitas produksi minyak di Indonesia mengalami penurunan jika dibandingkan dengan dekade tahun 1970-an. Pada dekade tahun 1970-an kapasitas produksi minyak di Indonesia masih sekitar 1,3 juta barel per hari. Namun saat ini, kapasitas produksi minyak di Indonesia hanya 1,070 juta barel per hari. Kondisi seperti ini terjadi disamping karena lapangan yang sudah tua dan penurunan kapasitas produksi minyak mentah Indonesia, juga dikarenakan penurunan jumlah penemuan cadangan minyak baru di Indonesia. Kondisi seperti inilah yang menyebabkan Negara Indonesia tidak mampu mencukupi kebutuhan bahan bakar minyak negaranya sendiri dan harus mengimpor dari luar negeri sejak tahun 2000 (Yakinudin, 2016). Disamping itu, cadangan minyak di Indonesia diperkirakan hanya akan cukup untuk memenuhi kebutuhan selama 18 tahun mendatang (Azhar, 2016).

Indonesia sudah berada dalam krisis energi karena sangat tergantung dengan bahan bakar fosil terutama minyak bumi yang memberatkan APBN dan menguras devisa negara. Hal ini dikarenakan cadangan minyak bumi di Indonesia kian menipis dan harus mengimpor kebutuhan minyak bumi dari luar negeri (Hudaya, 2016). Oleh karena itu, Indonesia harus memiliki kemampuan (knowledge and technology) yang dipadukan dengan kearifan local (wisdom) dalam mengatasi permasalahan energi.

Diversifikasi energi Indonesia sudah mulai mendapat perhatian serius dari pemerintah setelah dikeluarnya peraturan pemerintah nomor 79 tahun 2014, mengenai kebijakan energi nasional. Pemerintah mentargetkan pada tahun 2025 peran Energi Baru dan Energi Terbarukan paling sedikit 23\% dan pada tahun 2050 paling sedikit 31\% (Purnomo, et al., 2020).

Sebenarnya ada jalan keluar yang dapat dilakukan untuk mengentaskan masalah ancaman kelangkaan sumber energi minyak bumi di Indonesia. Jalan keluar tersebut salah satunya dengan mengembangkan sumber energi terbaharukan, seperti sinar matahari, panas bumi, air, angin, dan bahan bakar nabati (biofuel) (Yakinudin, 2016). Dari beberapa pilihan sumber energi terbaharukan tersebut, yang paling potensial dikembangkan bagi masyarakat di Kabupaten Blitar adalah dengan mengembangkan sumber energi terbaharukan dengan teknologi bioetanol. Pengembangan sumber energi bioetanol ini sangat cocok dilakukan mengingat sumber enargi ini berasal dari bahan nabati 
yang merupakan sumber daya alam yang mudah diperbaharui dan banyak tersedia di Kabupaten Blitar.

Penerapan dan pengembangan teknologi bioetanol sangat potensial dilakukan di Indonesia termasuk di Kabupaten Blitar, mengingat Kabupaten Blitar merupakan wilayah yang memiliki sumber daya alam khususnya tanah yang sangat subur, sehingga dengan kondisi tanah yang subur ini, dapat digunakan untuk memproduksi bahan dasar bioetanol secara mudah. Salah satu bahan dasar yang dapat digunakan untuk memproduksi bioetanol adalah ketela pohon yang sangat mudah dibudidayakan di wilayah Kabupaten Blitar.

Kabupaten Blitar merupakan sebuah kawasan di Provinsi Jawa Timur-Indonesia yang sebagian besar tanahnya tergolong subur khususnya di wilayah bagian utara. Kabupaten Blitar bagian utara merupakan dataran rendah dan dataran tinggi dengan ketinggian antara 105 - 349 meter di atas permukaan laut, dan keberadaanya dekat dengan Gunung Kelud yang merupakan gunung berapi aktif sehingga membuat struktur tanah di kawasan ini sangat subur dan banyak dilalui oleh aliran sungai. Daerah yang termasuk bagian utara Kabupaten Blitar meliputi Kecamatan: Kanigoro, Talun, Selopuro, Kesamben, Doko, Wlingi, Gandusari, Garum, Nglegok, Sanankulon, Ponggok, Srengat, Wonodadi dan Udanawu (BPS Kabupaten Blitar, 2020).

Sementara itu, untuk wilayah bagian selatan, sebagian wilayahnya merupakan daerah pesisir, dan pegunungan berbatu sehingga struktur tanah di kawasan ini kurang subur bila dibandingkan dengan wilayah Kabupaten Blitar bagian utara. Namun demikian, wilayah bagian selatan ini masih potensial bila digunakan untuk menanam tanaman seperti pohon ketela sebagai bahan pokok pembuatan bioetanol. Adapun wilayah di Kabupaten Blitar yang masuk kawasan bagian selatan meliputi Kecamatan: Bakung, Wonotirto, Panggungrejo, Wates, Binangun, Sutojayan dan Kademangan (BPS Kabupaten Blitar, 2020).

Dengan kondisi sumber daya alam berupa tanah yang subur, tidak heran jika sebagian besar masyarakat di Kabupaten Blitar memilih memanfaatkan tanah sawah/perkebunan yang dimiliki untuk kegiatan bercocok tanam (bertani/berkebun). Hampir separoh dari seluruh masyarakat di Kabupaten Blitar memiliki mata pencaharian di bidang pertanian. Adapun masyarakat Kabupaten Blitar yang bekerja di sektor pertanian sebasar $43,74 \%$ dari total seluruh jenis mata pencaharian yang ada di Kabupaten Blita. Adapun luas tanah di wilayah Kabupaten Blitar yang digunakan untuk kegiatan pertanian sebesar 19,96\%, sementara itu untuk perkebunan sebesar 28,29\% (BPS Kabupaten Blitar, 2020). Dengan demikian dapat diketahui bahwa hampir separoh dari seluruh wilayah di Kabupaten Blitar merupakan kawasan yang digunakan untuk kegiatan bercocok tanam (bertani dan berkebun).

Dengan kekayaan alam yang dimiliki berupa tanah yang subur dan lahan pertanian yang luas untuk kegiatan bercocok tanam (bertani/berkebun), seharusnya masyarakat petani di Kabupaten Blitar hidup makmur dan sejahtera. Akan tetapi pada kenyataannya, Kabupaten Blitar merupakan kawasan yang masih tergolong memiliki tingkat kemiskinan yang tinggi. Dapat dikatakan bahwa Kabupaten Blitar merupakan kabupaten yang masyarakatnya masih banyak yang berasal dari kalangan ekonomi bawah (masyarakat miskin). Adapun data yang ada menyatakan bahwa jumlah masyarakat miskin di Kabupaten Blitar mengalami peningkatan mencapai 70 ribu jiwa (Arif, 2012). Pernyataan ini diperkuat oleh data BPS Kabupaten Blitar yang menyatakan bahwa dari total 478.043 penduduk Kabupaten Blitar, 154.879 penduduk diantaranya merupakan masyarakat yang berasal dari keluarga miskin (Amilyaayu, 2011). Dari data di atas dapat diketahui bahwa lebih dari seperempat persen dari total penduduk Kabupaten Blitar merupakan masyarakat yang berasal dari keluarga Miskin. Dibawah ini merupakan tabel jumlah penduduk miskin di Kabupaten Blitar berdasarkan asal kecamatan. 
Tabel 1 Jumlah Penduduk Miskin Menurut Kecamatan di Kabupaten Blitar

\begin{tabular}{|c|c|c|c|c|c|c|}
\hline \multirow{2}{*}{ No } & \multirow{2}{*}{ Kecamatan } & \multirow{2}{*}{$\begin{array}{c}\text { Jumlah KK } \\
\text { (jiwa) }\end{array}$} & \multirow{2}{*}{$\begin{array}{l}\text { Jumlah } \\
\text { Jiwa }\end{array}$} & \multicolumn{3}{|c|}{ Jumlah Keluarga Miskin (iiwa) } \\
\hline & & & & Pra S & KSI & Total \\
\hline 1 & Bakung & 6.446 & 16.643 & 5.126 & 1.320 & 6.446 \\
\hline 2 & Sutojayan & 6.056 & 18.267 & 4.551 & 1.505 & 6,056 \\
\hline 3 & Panggungrejo & 3,692 & 11,759 & 1,241 & 2,451 & 3,692 \\
\hline 4 & Wates & 10,415 & 32,425 & 3.224 & 7.191 & 10.415 \\
\hline 5 & Binangun & 7,129 & 22.278 & 3,161 & 3.968 & 7,129 \\
\hline 6 & Kesamben & 11.010 & 33,044 & 5,738 & 5.272 & 11.010 \\
\hline 7 & Doko & 7.474 & 24,593 & 2,565 & 4,909 & 7.474 \\
\hline 8 & Wlingi & 6.927 & 23,650 & 3,694 & 3,233 & 6,927 \\
\hline 9 & Talun & 9.771 & 31,264 & 2,665 & 7,106 & 9.771 \\
\hline 10 & Kanigoro & 7.711 & 22.937 & 4,424 & 3.287 & 7.711 \\
\hline 11 & Kademangan & 12.504 & 39,673 & 3,487 & 9.017 & 12.504 \\
\hline 12 & Sanankulon & 6.136 & 19,350 & 2,671 & 3.465 & 6,136 \\
\hline 13 & Srengat & 6,061 & 18,961 & 1,250 & 4,811 & 6,061 \\
\hline 14 & Udanawu & 6,459 & 21,833 & 2,156 & 4,303 & 6,459 \\
\hline 15 & Ponggok & 6.311 & 19,449 & 2,741 & 3.570 & 6,311 \\
\hline 16 & Nglegok & 6.034 & 14.276 & 2.323 & 3.711 & 6.034 \\
\hline 17 & Garum & 8.957 & 28,276 & 3,013 & 5,944 & 8,957 \\
\hline 18 & Gandusari & 4.467 & 14.552 & 2.500 & 1.967 & 4.467 \\
\hline 19 & Wonodadi & 4,109 & 12.800 & 2,155 & 1,954 & 4,109 \\
\hline 20 & Wonotirto & 6.270 & 19,422 & 2.735 & 3.535 & 6.270 \\
\hline 21 & Selorejo & 3.884 & 12.184 & 1.171 & 2.713 & 3.884 \\
\hline 22 & Selopuro & 7.056 & 20,407 & 4,034 & 3,022 & 7,056 \\
\hline & Jumlah & 154.879 & 478,043 & 66,625 & 88,254 & 154.879 \\
\hline
\end{tabular}

Keterangan:

Pra S : Kategori Keluarga Sangat Miskin

KS I: Kategori Keluarga Miskin

Kemiskinan yang dialami oleh masyarakat yang bekerja di sektor pertanian ternyata tidak hanya terjadi di wilayah Kabupaten Blitar, namun terjadi hampir di seluruh masyarakat pertanian yang ada di Indonesia. Dari hasil penelitian yang dilakukan oleh Soesilo dan Suman (2008) dengan judul "Penyebab Kemiskinan Masyarakat Tani (Studi di Dusun Ngebrong, Desa Tawangsari, Kecamatan Pujon, Kabupaten Malang)" menunjukkan bahwa penyebab kemiskinan masyarakat pertanian dikarenakan rendahnya harga jual produk pertanian sementara tingginya harga untuk biaya pengolahan produk pertanian (Soesilo \& Agus Suman, 2008). Produk pertanian yang dijual secara mentah misalnya dijual dalam bentuk gabah (padi yang belum dikupas kulitnya), beras, biji jagung, ketala, dan seterusnya, harganya akan cenderung rendah. Apalagi pemerintah selalu campur tangan dalam menentukan harga produk hasil pertanian. Campur tangan pemerintah tersebut cenderung menjaga agar harganya produk hasil pertanian selalu rendah. Bahkan, jika harga produk pertanian tinggi, pemerintah akan berupaya untuk menurunkan harga dengan melakukan impor produk pertanian dari luar negeri. Kebijakan ini tentu saja sangat tidak "pro" terhadap masyarakat pertanian. Apalagi biaya yang digunakan untuk mengolah produk pertanian relatif tinggi. Mulai dari biaya tenaga kerja untuk mengolah lahan pertanian, sewa/beli alat pertanian, membeli bahan bakar minyak untuk menjalankan alat-alat pertanian, membeli pestisida, membeli pupuk, dan bahkan biaya pengairan ketika musim kemarau. Kondisi seperti ini tentu saja sangat merugikan masyarakat yang mata pencahariannya sebagai seorang petani.

Produk pertanian yang dijual mentah harganya memang relatif rendah, namun produk pertanian yang dijual dengan melalui proses pengolahan terlebih dahulu sehingga siap untuk dikonsumsi, harganya cenderung akan mengalami peningkatan. Misalnya saja harga roti merk "Holland" dan "Bread Talk" yang bahan dasarnya berasal dari produk pertanian, harganya bisa melambung tinggi karena dijual dalam bentuk produk jadi yang sudah siap untuk dikonsumsi. Bioetanol merupakan salah satu produk siap konsumsi yang bahan dasarnya dari hasil pertanian yaitu ketela pohon, sehingga harapannya harga jual dari produk ini bisa lebih tingggi jika dibandingkan dengan harga jual ketela pohon mentah. Namun demikian, harga jual bioetanol ini juga masih harus dapat bersaing dengan bahan bakar minyak yang berasal dari fosil.

Dengan melihat potensi masyarakat Kabupaten Blitar yang notabennya mayoritas adalah seorang petani, serta pontensi sumber daya alam di Kabupaten Blitar yang memiliki tanah yang subur dan lahan sawah/perkebunan yang luas. Penulis memiliki sebuah gagasan untuk meningkatkan perekonomian masyarakat petani di Kabupaten Blitar sekaligus menjawab kekhawatiran akan masalah kelangkaan pada sumber energi khususnya bahan bakar minyak. Ide yang penulis tawarkan 
ini bernama "Be KePo (Bioetanol Ketela Pohon): Alternatif Pengganti Bahan Bakar Minyak Fosil Sebagai Usaha Ekonomi Masyarakat Petani Kabupaten Blitar."

Be KePo merupakan alternatif pengganti bahan bakar minyak fosil yang berasal dari ketela pohon. Ketela pohon merupakan sumber daya alam yang dapat diperbaharui dan bahkan sangat mudah sekali ditanam dan dibudidayakan di wilayah Kabupaten Blitar. Bahkan secara sederhana dapat dikatakan bahwa batang ketela pohon yang ditancapkan di tanah (tanpa perawatan khusus), dapat tumbuh subur dengan sendirinya di wilayah Kabupaten Blitar. Dengan demikian jika tanaman ini dibudidayakan dan dirawat dengan baik di Wilayah Kabupaten Blitar, tentu saja akan tumbuh dengan subur dan menghasilkan produk ketela yang bagus dan melimpah sebagai bahan dasar pembuatan bahan bakar minyak bioetanol.

Usaha ekonomi masyarakat berupa bahan bakar minyak alternatif yang berasal dari ketela pohon ini, memiliki peluang yang cukup besar akan laris di pasaran dan meningkatkan pendapatan masyarakat petani di Kabupaten Blitar. Hal ini dikarenakan hampir semua masyarakat Kabupaten Blitar bahkan Masyarakat di Indonesia memiliki kendaraan bermotor sebagai alat transportasi yang tentu saja membutuhkan bahan bakar minyak sebagai sumber energi penggeraknya. Selain itu, alatalat industri besar maupun industri rumahan dan alat-alat pertanian sebagian besar juga masih menggunakan bahan bakar minyak sebagai sumber energi penggeraknya. Dengan demikian dapat dikatakan bahwa bahan bakar minyak bioetanol ini masih sangat dibutuhkan oleh masyarakat baik sekala lokal, nasional, bahkan internasional. Jika usaha Be Kepo ini dapat dijalankan dengan baik oleh masyarakat petani di Kabupaten Blitar, tentu saja akan meningkatkan kesejahteraan ekonomi masyarakat di Kabupaten Blitar, serta secara otomatis akan menurunkan tingkat kemiskinan masyarakat sebagai pelaku usaha produk Be Kepo ini.

\section{METODE PENELITIAN}

Kegiatan pemberdayaan masyarakat untuk meningkatkan perekonomian masyarakat petani di Kabupaten Blitar sekaligus sebagai solusi sumber energi alternatif ini menggunakan metode pendekatan participatory rural appraisal yang melibatkan peran masyarakat secara aktif dalam pelaksanaan kegiatan pengabdian kepada masyarakat. Adapun tahap-tapap yang perludilakukan mencakup (Mustanir, Ibrahim, Sapri, \& Razak, 2020):

Tahap pertama: Identifikasi permasalahan yang dihadapi petani di Kabupaten Blitar. Tahap pertama ini dilakukan untuk mencari informasi dari permasaahan yang dihadapi oleh para petani. Proses yang dikalukan dengan melakukan observasi dan diskusi. Kemudian menentukan permasalahan utama yang dapat diselesaikan bersama-sama dengan para petani. Permasalahan yang diangkat harus dapat mempertimbangkan potensi yang dimiliki masyarakat tersebut. Dari hasil observasi dan diskusi maka salah satu permasalahan yang akan diselesaikan adalah permasalahan rendahnya harga jual produk pertanian khususnya ketela pohon yang ketersediaannya sangat melimpah di Kabupaten Blitar. Permasalahan ini kemudian dianalisis dan dirumuskan sebuah ide untuk mengubah produk ketela pohon menjadi bahan bakar minyak yang sangat dibutuhkan oleh masyarakat luas yaitu bioethanol.

Tahap kedua: Desain dan implementasi konversi ketela pohon menjadi bioetanol. Untuk membuat bioetanol ada beberapa hal yang harus dilakukan, diantarnya adalah proses hidrolisis (proses persiapan bahan baku, yakni proses konversi pati menjadi glukosa), proses fermentasi (proses konversi glukose (gula) menjadi etanol dan $\mathrm{CO}_{2}$ ), poses pemurnian atau proses distilasi (proses pemurnian etanol hasil fermentasi menjadi etanol dengan kadar 95-96\%), dan proses dehidrasi (proses penghilangan air dari 96\% menjadi 99,5\%).

Tahap ketiga: Pendampingan implementasi pembuatan bioethanol dan pemasaran. Pendampingan kepada mitra pengabdian (masyarakat petani Kabupaten Blitar) diperlukan agar keberlanjutan pengolahan ketela pohon menjadi bioetanol mendapatkan hasil yang optimal. Dalam pendampingan ini mitra dibekali bagaimana cara mengoperasikan mesin, mengkonversi energi, perawatan dan perbaikan terhadap mesin/alat, serta pemasaran produk hasil olahan (Habib, 2021). 
Sementara itu, metode penulisan artikel ini menggunakan metode studi pustaka. Data-data yang digunakan berasal dari berbagai jurnal ilmiah, laporan hasil penelitian, serta berita di media massa yang terpercaya. Data-data tersebut dihimpun, kemudian dieliminasi, dan dianalisis untuk mendukung ide inovatif dari penulis memecahkan permasalahan kemiskinan dan kelangkaan sumber energi.

\section{HASIL PENELITIAN DAN PEMBAHASAN}

\section{a. Kemiskinan Masyarakat Petani di Kabupaten Blitar}

Masyarakat yang bekerja di sektor pertanian, sampai saat ini masih banyak yang berada di bawah garis kemiskinan. Kondisi ini tidak hanya terjadi di wilayah Kabupaten Blitar, namun terjadi hampir di seluruh masyarakat pertanian yang ada di Indonesia. Hasil penelitian yang dilakukan oleh Soesilo dkk (2008) menunjukkan bahwa penyebab kemiskinan masyarakat pertanian dikarenakan rendahnya harga jual produk pertanian dan tingginya biaya perawatan produk pertanian (Soesilo \& Agus Suman, 2008). Produk pertanian yang dijual secara mentah (belum siap konsumsi) harganya akan cenderung rendah. Apalagi pemerintah selalu ikut campur dalam menentukan harga produk hasil pertanian agar selalu rendah. Bahkan, jika harga naik, pemerintah akan berupaya membuat kebijakan untuk menurunkan harga dengan melakukan impor. Kebijakan ini tentu saja sangat tidak "pro" pada masyarakat pertanian. Disamping itu, biaya yang digunakan untuk mengolah produk pertanian tidaklah murah, mulai dari biaya tenaga kerja sampai pembelian bahan-bahan untuk perawatan tanaman yang di tanam. Kondisi seperti inilah yang membuat masyarakat petani khususnya di Kabupaten Blitar susah untuk keluar dari belenggu kemiskinan.

Melalui inovasi Be Kepo ini, petani tidak akan lagi menjual produk pertanian secara mentah. Namun mereka akan mengolahnya terlebih dahulu menjadi bioetanol yang siap konsumsi sebagai bahan bakar alternatif pengganti bahan bakar minyak. Bioetanol ini dapat dipastikan akan laris di pasaran, baik di pasar lokal, nasional, maupun internasional. Hal ini dikarenakan masyarakat di seluruh dunia dapat dipastikan membutuhkan bahan bakar minyak sebagai penunjang kehidupan modern yang sarat akan penggunaan teknologi-teknologi modern untuk mempermudah dan mempercepat berbagai aktivitasnya. Teknologi-teknologi modern tersebut tentunya membutuhkan energi sebagai sumber penggerak, dan salah satu sumber energi yang sering digunakan adalah bahan bakar minyak. Bahan bakar minyak bioetanol yang berasal dari bahan nabati, tentu saja akan sangat diminati oleh masyarakat dunia karena ramah lingkungan dan tidak akan habis sebab berasal dari SDA yang dapat diperbaharui. Dengan usaha ekonomi yang dilakukan oleh masyarakat petani di Kabupaten Blitar ini, tentu saja akan meningkatkan kondisi ekonomi keluarga petani pelaku usaha Be Kepo.

Adapun manfaat dari gagasan yang penulis usung dengan nama Be Kepo ini adalah terselesaikannya dua masalah sekaligus yang saat ini sedang dihadapi oleh masyarakat di Kabupaten Blitar. Masalah pertama yaitu terselesaikannya ancaman kelangkaan bahan bakar minyak fosil. Kemudian masalah kedua yaitu terselesaikannnya masalah kemiskinan yang saat ini menyelimuti masysrakat petani di Kabupaten Blitar.

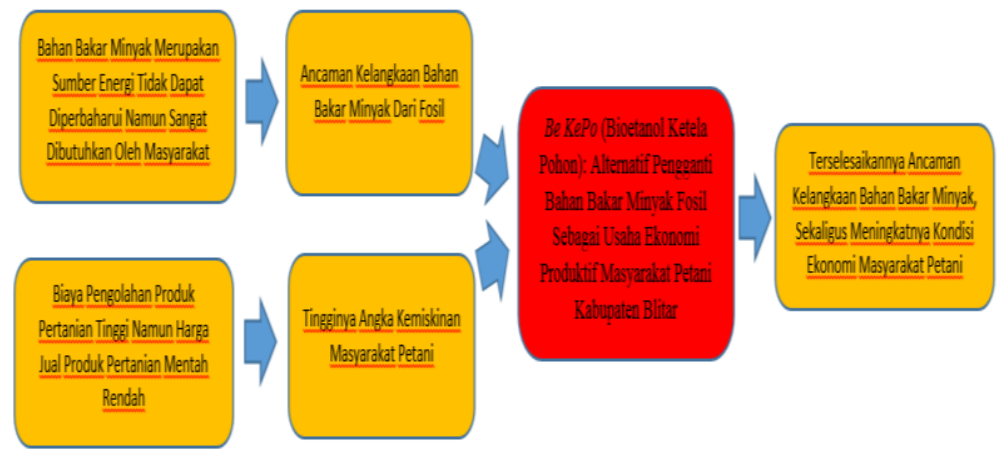

Gambar 1. Skema Manfaat Inovasi Be Kepo (Penulis, 2021) 


\section{b. Keuntungan Dibandingkan Dengan Inovasi yang Sudah Ada}

Dalam mensiasati ancaman kelangkaan bahan bakar minyak yang berasal dari fosil. Sebanarnya sudah cukup banyak dilakukan penemuan-penemuan teknologi terbaru yang tidak lagi menggunakan bahan bakar minyak fosil sebagai sumber energinya. Salah satu inovasi yang telah ada di Kabupaten Blitar adalah penggunaan energi dari sinar matahari (solar cell). Namun demikian ada beberapa kelemahan yang menyebabkan sumber energi ini sampai sekarang masih belum banyak diminati oleh masyarakat Kabupaten Blitar. Alasan rendahnya minat masyarakat terhadap teknologi Pembangkit Listrik Tenaga Surya (PLTS) karena biaya instalasi yang mahal bagi kalangan masyarakat dengan kondisi ekonomi menengah ke bawah. Biaya instalasi PLTS berkisar antara Rp 15 juta hingga Rp 30 juta (Frastuti \& Royda, 2020). Biaya ini tentu saja mahal bagi masysrakat di Kabupaten Blitar yang notabennya masih banyak yang berasal dari kalangan masyarakat ekonomi menengah ke bawah. Sementara itu, teknologi Be Kepo yang ditawarkan, tidak memerlukan biaya instalasi yang harus ditanggung oleh tiap-tiap konsumen. Konsumen cukup membeli produk layaknya membeli BBM Pertalite, sehingga bisa dengan mudah untuk memenuhi kebutuhan BBM kendaraan bermotor.

Kebutuhan akan energi listrik untuk usaha skala sedang sampai besar seperti hotel, rumah sakit, swalayan, industri rumahan maupun industri skala besar, umumnya menggunakan genset sebagai pembangkit energi listrik. Genset ini tentu saja memerlukan bahan bakar minyak sebagai sumber energi penggeraknya. Bahan bakar minyak yang berasal dari fosil untuk menggerakkan genset tersebut, dapat diganti dengan bahan bakar minyak bioetanol. Dengan demikian, bahan bakar minyak bioetanol merupakan bahan bakar minyak alternatif ytang dirasa cukup efektif untuk menggantikan peran/fungsi bahan bakar minyak yang berasal dari fosil.

Adapun inovasi yang telah dilakukan untuk mengatasi masalah kemiskinan yang dihadapi oleh masyarakat di Kabupaten Blitar yang terupdate adalah diselenggarakannya Program Keluarga Harapan (PKH) dari Kementerian Sosial. Kementerian sosial melalui para pekerja sosial yang tergabung dalam PKH telah dan sedang menyelenggarakan program untuk membantu masyarakat miskin di Kabupaten Blitar. Bahkan dari informasi yang penulis dapatkan dari Dinas Sosial Kabupaten Blitar, Kabupaten Blitar merupakan daerah dengan jumlah pekerja sosial PKH terbanyak di Jawa Timur dan jumlah bantuan yang disalurkan juga terbanyak di Jawa Timur. Akan tetapi program PKH tersebut dirasa masih kurang efektif karena lebih memfokuskan pada penyaluran bantuan dan bukan pada pemberdayaan masyarakat melalui usaha ekonomi produktif. Memang dalam PKH ada program pemberdayaan masyarakat melalui usaha ekonomi produktif di setiap kecamatan, namun hal itu menurut pengamatan penulis kurang menyeluruh dan hanya dinomor duakan. Sementara itu fokus utama program PKH berupa penyaluran bantuan dari pemerintah ke masyarakat miskin.

Fokus utama PKH berupa penyaluran bantuan dari pemerintah ke masyarakat miskin inilah yang dirasa kurang efektif dalam mengentaskan kemiskinan masyarakat di Kabupaten Blitar. Bagaimana tidak, jika masyarakat miskin hanya diberikan bantuan saja tanpa diberdayakan lebih lanjut, tentu saja akan menanamkan mental miskin pada masyarakat. Mental miskin inilah yang kemudian membuat masyarakat terus berharap mendapat bantuan dari pemerintah tanpa tahu bagaimana cara menjadi orang yang berdaya. Sementara itu program Be Kepo yang penulis usung ini, sifatnya memberdayakan masyarakat agar mereka mempunyai usaha/bisnis di bidang energi alternatif untuk melepaskan mata rantai kemiskinan yang selama ini membelenggu mereka.

\section{c. Kelebihan Be Kepo (Bioetanol Ketela Pohon)}

Bioetanol merupakan bahan bakar minyak yang ramah lingkungan. Dikatakan ramah lingkungan karena kadar $\mathrm{CO} 2$ yang dihasilkan dari hasil pembungan mesin yang menggunakan bahan bakar bioetanol dapat dengan mudah diserap oleh tanaman, selanjutnya tanaman yang menyerap $\mathrm{CO} 2$ tersebut selanjutnya manfaatkan kembali sebagai bahan baku pembuatan bioetanol, begitu seterusnya, sehingga tidak menyebabkan terjadinya akumulasi karbondioksida di atmosfer, seperti yang ditimbulkan oleh penggunaan bahan bakar minyak yang berasal dari fosil (Wiratmaja \& Elisa, 2020). Keunggulan lain dari bioetanol adalah bioetanol mempunyai angka oktan yang tinggi yaitu 135. Sementara itu angka oktan bahan bakar minyak premium yang saat ini dijual di pasaran hanya sebesar 98. Padahal semakin tinggi bilangan oktan pada bahan bakar minyak, bahan bakar minyak 
tersebut akan semakin tahan untuk tidak mudah terbakar sendiri sehingga menghasilkan kestabilan proses pembakaran. Proses pembakaran yang stabil tersebut akan menghasilkan daya yang semakin stabil pula. Proses pembakaran dengan daya yang lebih sempurna akan mengurangi emisi gas karbon monoksida. Campuran bioetanol 3\% saja pada bahan bakar minyak yang berasal dari fosil, mampu menurunkan emisi karbon monoksida menjadi hanya 1,35\%. Bioetanol dapat juga meningkatkan efisiensi pembakaran karena mengandung 35\% oksigen sehingga sangat ramah lingkungan karena emisi gas buangan seperti kadar karbon monoksida, nitrogen oksida, dan gas-gas lain lebih rendah yaitu antara 19-25\% (Safitri, 2013).

Sumber bioetanol yang cukup potensial dikembangkan di Indonesia termasuk di Kabupaten Blitar adalah singkong atau ketela pohon (manihot esculenta). Ketela pohon merupakan tanaman yang sudah dikenal sejak lama oleh petani di Indonesia, walaupun bukan tanaman asli dari Indonesia. Ketela pohon pertama kali didatangkan oleh Pemerintah Kolonial Belanda pada wal abad ke-19 dari Amerika Latin. Karena sudah dikenal lama oleh petani di Indonesia termasuk juga petani di Kabupaten Blitar, pengembangan ketela pohon sebagai bahan dasar pembuatan bioetanol dipastikan tidak akan terlalu susah. Saat ini ketela pohon yang berasal dari Indonesia banyak yang diekspor ke Amerika Serikat dan ke Eropa dalam bentuk tapioka. Di negara tersebut, ketela pohon dimanfaatkan sebagai bahan baku industri pembuatan alkohol. Tepung tapioka juga digunakan dalam industri lem, kimia dan tekstil. Negara Indonesia adalah penghasil ketela pohon terbesar keempat di dunia, namun pemanfaatan ketela pohon di Indonesia masih sangat tradisional. Biasanya di Indonesia ketela pohon hanya digunakan sebagai pakan ternak dan bahan pembuat makanan tradisional yang kurang diminati oleh masyarakat. Karena hal itu, harga ketela pohon di Indonesia menjadi relatif rendah dan tidak memberikan keuntungan yang memadahi bagi petani yang menanamnya. Pengambangan teknologi bioetanol ini diharapkan dapat meningkatkan pendapatan petani singkong dan mensejahterakan kehidupan para petani singkong tersebut khususnya di Kabupaten Blitar (Safitri, 2013).

\section{d. Keberlanjutan Inovasi}

Program "Be KePo (Bioetanol Ketela Pohon): Alternatif Pengganti Bahan Bakar Minyak Fosil Sebagai Usaha Ekonomi Produktif Masyarakat Petani Kabupaten Blitar" ini merupakan sebuah program yang memiliki prospek bagus ke depannya. Program ini memang membutuhkan sejumlah dana di awal pelaksanaannya, bisa bersumber dari pemerintah maupun swadaya masyarakat. Namun dana tersebut cukup diberikan sekali di awal pelaksanaannya. Selanjutnya program ini akan menghasilkan profit yang dapat digunakan untuk mensejahterakan masyarakat. Secara teknis, pelaksanaan program Be Kepo ini dirancang sebagai program pemberdayaan dari pemerintah yang dapat dilaksanakan melalui beberapa tahap yaitu:

1. Pemerintah melalui Kementerian Sosial mengesahkan program Be Kepo untuk memberdayakan masyarakat miskin khususnya yang bekerja di sektor pertanian namun tidak menutup kemungkinan masyarakat miskin yang bekerja di sekotor lain bisa bergabung dalam program ini.

2. Setelah program ini disahkan, pemerintah menyiapkan anggaran dana untuk pelaksanaan program Be Kepo. Dana anggaran bisa berasal dari pengalihan/perubahan fungsi dari yang sebelumnya untuk Program Keluarga Harapan (PKH), dialihkan untuk usaha ekonomi produktif masyarakat penerima manfaat. Sehingga tidak menambah anggaran dana untuk pelaksanaan program Be Kepo ini. Pemerintah Kabupaten Blitar melalui Dinas Sosial dapat mengusulkan pengalihan penggunaan dana bantuan ke Kementerian Sosial, dari yang sebelumnya hanya diberi secara cas dan cuma-cuma kepada masyarakat, kali ini diberi untuk modal usaha bersama secara berkelompok.

3. Kementerian Sosial melalui Direktorat Penanggulangan Kemiskinan Pedasaan sebagai pelaksana program PKH memberikan surat perintah kepada pekerja sosial pelaksana PKH untuk membantu menjalankan program Be Kepo. Namun sebelumnya tentu saja pemerintah harus memberikan pelatihan/training terlebih dahulu kepada para pekerja sosial pelaksana program ini. 
4. Program ini bisa dikatakan sangat murah karena tidak menambah anggaran dana pemerintah sebab hanya pengalihan penggunaan dana dari yang sebelumnya diberikan secara cas dan cuma-cuma, namun kali ini dirubah untuk modal usaha ekonomi produktif. Selain itu, para pekerja sosial pelaksana program Be Kepo ini juga telah mendapat gaji dari program PKH sehingga tidak perlu lagi menambah dana anggaran untuk menggaji para pekerja sosial pendamping pelaksana program Be Kepo.

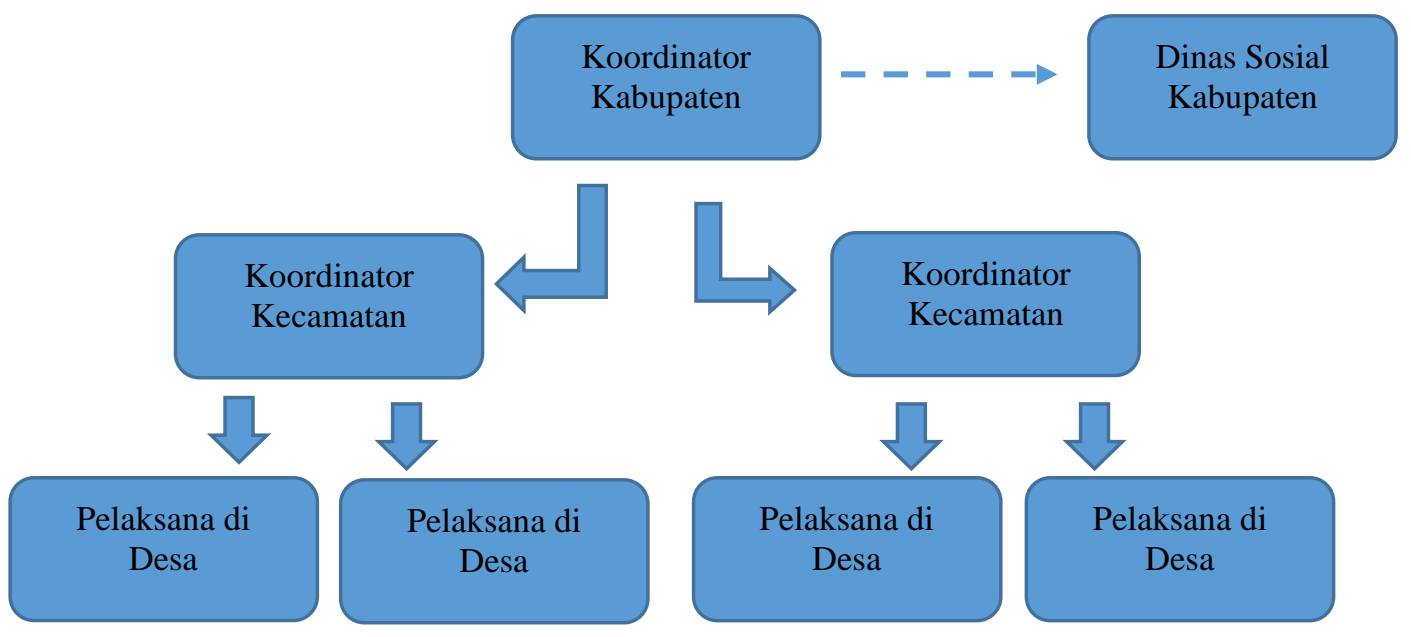

Gambar 2. Struktur Organisasi Pekerja Sosial Pelaksana Program Be Kepo (Penulis, 2021)

5. Para pekerja sosial yang telah tergabung dalam program Be Kepo melakukan pendataan dan penilaian kapada masyarakat calon penerima bantuan modal program Be Kepo untuk mendapatkan data masyarakat miskin khususnya petani miskin yang layak diberikan modal usaha.

6. Para pekerja sosial melaksanakan sosialisasi program Be Kepo kepada masyarakat yang tergabung dalam kelompok tani maupun masyarakat petani yang tidak tergabung dalam kelompok tani di tiap-tiap desa

7. Salah satu syarat calon penerima modal bantuan yang perlu disosialisasikan adalah berupa kelompok tani yang beranggotakan minimal 10 orang, dan diupayakan setiap RT minimal memiliki 1 kelompok tani yang akan diberikan modal usaha. Masyarakat di luar tani yang ingin bergabung dalam kelompok tani ini juga diperbolehkan. Jika dalam suatu kawasan belum ada kelompok tani, pekerja sosial dapat membantu membentuk kelompok tani.

8. Kelompok tani yang telah terbentuk diminta membuat proposal permohonan dana bantuan modal usaha untuk pelaksanaan program Be Kepo.

9. Proposal dana bantuan yang telah dibuat oleh kelompok tani kemudian diberikan kepada pekerja sosial untuk diperiksa kelengkapan dan kebenarannya, apabila proposal yang dikumpulkan masih ada yang salah atau kurang lengkap, pekerja sosial meminta kepada kelompok tani untuk memperbaikinya.

10. Proposal yang telah lengkap dan benar kemudian dikirim ke pemerintah yaitu ke Direktorat Penanggulangan Kemiskinan Pedasaan untuk kemudian disiapkan dana bantuan modal usaha.

11. Dana modal bantuan diserahkan ke kelompok tani untuk pelaksanaan program Be Kepo melalui pekerja sosial.

12. Pekerja sosial mengawasi, memandu, dan membantu pelaksanaan program Be Kepo di tiap-tiap desa

13. Setelah program ini berjalan dan dana bantuan telah terserap untuk modal usaha, selanjutnya pekerja sosial menghimpun laporan pertanggungjawaban penggunaan dana bantuan dari kelompok tani pelaksana program Be Kepo. Laporan pertanggungjawaban yang telah lengkap dan benar kemudian dikirim ke Direktorat Penanggulangan Kemiskinan Pedasaan, Kementerian Sosial RI. 
14. Dalam program ini, pemerintah juga harus menyediakan sarana dan prasarana untuk proses penyaluran atau penjualan bahan bakar minya bioetanol. Seperti bekerjasama dengan pertamina untuk menjual bahan bakar minyak bioetanol ini ke seluruh Indonesia, bahkan jika jumlahnya telah melimpah, pemerintah dapat membantu proses ekspor bioetanol ke luar negeri.

15. Setelah program ini berhasil dilaksanakan dan sukses mengentaskan kemiskinan bagi masyarakat petani di Kabupaten Blitar. Pemerintah dapat meniru model usaha ini untuk memberdayakan masyarakat miskin di daerah lain.

16. Harapannya setelah program ini berhasil, Kabupaten Blitar bisa menjadi kawasan produsen bioetanol terbesar di Indonesia dan mampu mencetak para pengusaha bioetanol yang sukses dan sejahtera.

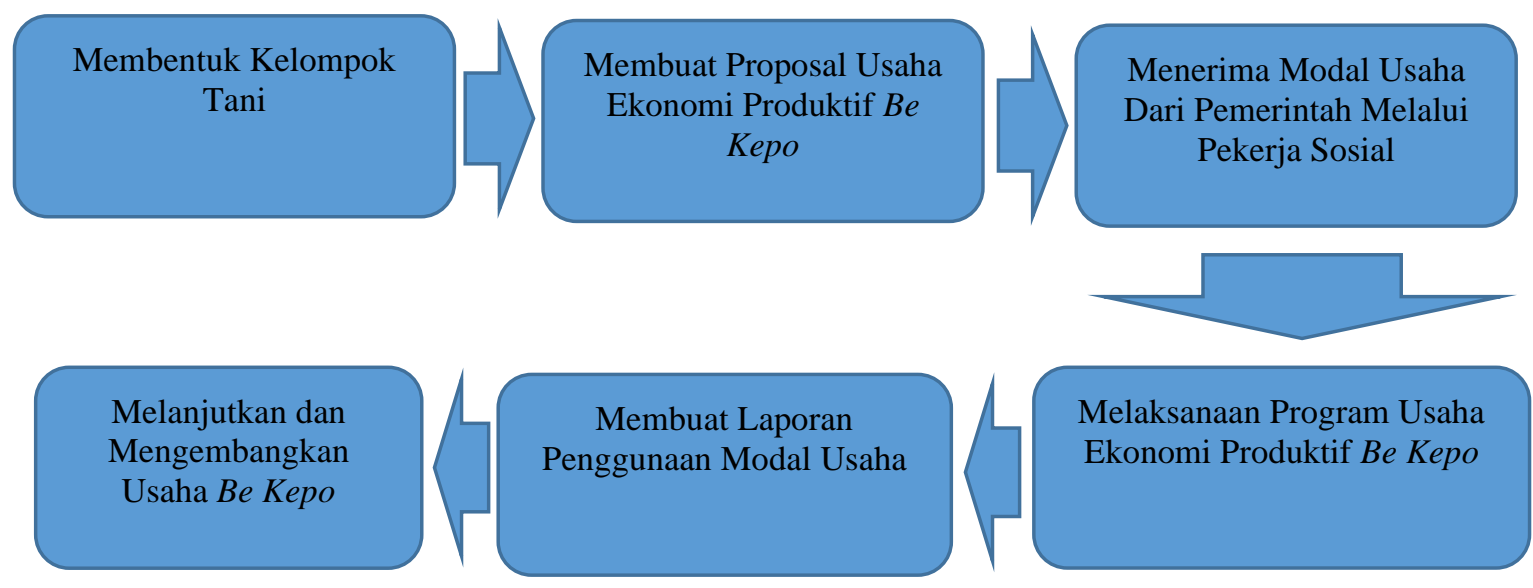

Gambar 3. Alur Pelaksanaan Program Be Kepo (Penulis, 2021)

\section{Teknis Pembuatan Bioetanol}

Secara sederhana, proses produksi bioetanol dari singkong mencakup 4 tahap yaitu :

1. Proses hidrolisis (proses persiapan bahan baku), yakni proses konversi pati menjadi glukosa;

2. Proses fermentasi, yaitu proses konversi glukose (gula) menjadi etanol dan $\mathrm{CO} 2$; dan

3. Poses pemurnian (proses distilasi), adalah proses pemurnian etanol hasil fermentasi menjadi etanol dengan kadar $95-96 \%$

4. Proses dehidrasi, adalah proses penghilangan air dari $96 \%$ menjadi $99,5 \%$. berikut:

Adapun secara detail proses produksi bioetanol dapat dilakukan melalui tahapan sebagai

1. Kupas $25 \mathrm{~kg}$ ketela pohon (manihot esculenta) segar, semua jenis dapat dimanfaatkan. Bersihkan dan giling hingga menjadi bubur.

2. Masukkan hasil gilingan ketela pohon ke dalam tangki stainless steel berkapasitas $\mathbf{1 2 0}$ liter, lalu tambahkan air hingga mencapai volume 100 liter.

3. Kandungan karbohidrat berupa tepung atau pati pada bahan baku ketela pohon dikonversi menjadi gula komplex menggunakan Enzyme Alpha Amylase melalui proses pemanasan (pemasakan) pada suhu 90 derajat celcius (hidrolisis). Pada kondisi ini tepung akan mengalami gelatinasi (mengental seperti Jelly). Pada kondisi optimum Enzyme Alpha Amylase bekerja memecahkan struktur tepung secara kimia menjadi gula komplex (dextrin). Proses hidrolisis selesai ditandai dengan parameter dimana bubur yang diproses berubah menjadi lebih cair seperti sup 
4. Masukkan cendawan saccharomyces cerevisiae (ragi tepe) yang akan memecah pati menjadi glukosa. Untuk menguraikan 100 liter bubur pati ketela pohon, diperlukan 10 liter larutan cendawan ini atau $10 \%$ dari total bubur.

5. Dua jam kemudian, bubur berubah menjadi 2 lapisan, air dan endapan gula. Aduk kembali pati yang sudah menjadi gula, lalu masukkan dalam tangki fermentasi.

6. Tutup rapat tangki fermentasi untuk mencegah kontaminasi dan cendawan bekerja lebih optimal. Fermentasi berlangsung anaerob alias tidak membutuhkan oksigen. Agar fermentasi optimal, jaga suhu pada $28-32 \mathrm{C}$ dan $\mathrm{pH} \mathrm{4,5-5,5}$.

7. Setelah $2-3$ hari, larutan pati berubah menjadi 3 lapisan. Lapisan terbawah berupa endapan protein. Di atasnya air dan etanol. Hasil fermentasi itu mengandung $6-12 \%$ etanol.

8. Panaskan campuran air dan etanol pada suhu $78 \mathrm{C}$ atau setara titik didih etanol. Pada suhu itu etanol lebih dahulu menguap dan dialirkan melalui pipa yang terendam air sehingga terkondensasi dan kembali menjadi etanol cair.

9. Hasil penyulingan berupa $95 \%$ etanol dan tidak dapat larut dalam bensin. Agar larut, diperlukan etanol berkadar $99 \%$ atau disebut etanol kering. Oleh sebab itu, perlu destilasi absorbent. Etanol itu dipanaskan $100 \mathrm{C}$, kemudian uap tersebut disalurkan ke dalam pipa yang dindingnya berlapis zeolit.

10. Zeolit atau batu gamping akan menyerap kadar air tersisa hingga diperoleh etanol $99 \%$ yang siap untuk digunakan.

11. Untuk $25 \mathrm{~kg}$ ketela pohon mampu menghasilkan sekitar 10 liter bioethanol.

\section{Kisaran Biaya Skala Home Industri}

\section{Biaya Pembuatan Alat Bioetanol}

\begin{tabular}{|l|l|c|r|}
\hline NO & \multicolumn{1}{|c|}{ NAMA ALAT } & SATUAN & HARGA \\
\hline 1 & Tangki Stainless Steel 250 L & 1 buah & Rp. 2.300 .000 \\
\hline 2 & Tangki Air 250 L & 1 buah & Rp. 600.000 \\
\hline 3 & Pipa Tembaga & 15 meter & Rp. 600.000 \\
\hline 4 & Tungku Pemanas/Kompor & 1 buah & Rp. 300.000 \\
\hline 5 & Thermocouple & 2 buah & Rp. 100.000 \\
\hline \multicolumn{2}{|c|}{ Total 3.900 .000} \\
\hline
\end{tabular}

Harga Bahan Dasar (Per 10 Liter Bioethanol)

\begin{tabular}{|l|l|c|r|}
\hline No & \multicolumn{1}{|c|}{ Nama Bahan } & Satuan & Harga \\
\hline 1. & Ketela Pohon & $25 \mathrm{~kg}$ & Rp. 62.500 \\
\hline 2. & Air & 100 liter & Rp 0 \\
\hline 3. & $\begin{array}{l}\text { Ragi Tape (cendawan } \\
\text { saccharomyces cerevisiae) }\end{array}$ & 1 bungkus \\
\hline 4. & Enzyme Alpha Amylase & $1 / 4 \mathrm{~kg}$ & $\mathrm{Rp} 5.000$ \\
\hline \multicolumn{2}{|c|}{ Total } & & $\mathrm{Rp} 79.500$ \\
\hline
\end{tabular}

\section{Biaya Lain-Lain}

\begin{tabular}{|l|l|l|r|}
\hline No & \multicolumn{1}{|c|}{ Nama Bahan } & Satuan & Harga \\
\hline 1. & Pisau Kupas & 10 buah & Rp. 100.000 \\
\hline 2. & Ember & 10 buah & Rp 100.000 \\
\hline 3. & Timba & 4 buah & Rp 100.000 \\
\hline 4. & Baki & 4 buah & Rp 100.000 \\
\hline 5. & Pompa air & 1 Buah & Rp 500.000 \\
\hline 6. & Listrik & Rp 200.000 \\
\hline \multicolumn{2}{|c|}{ Total } & Rp 1.100 .000 \\
\hline
\end{tabular}




\section{Design Alat}

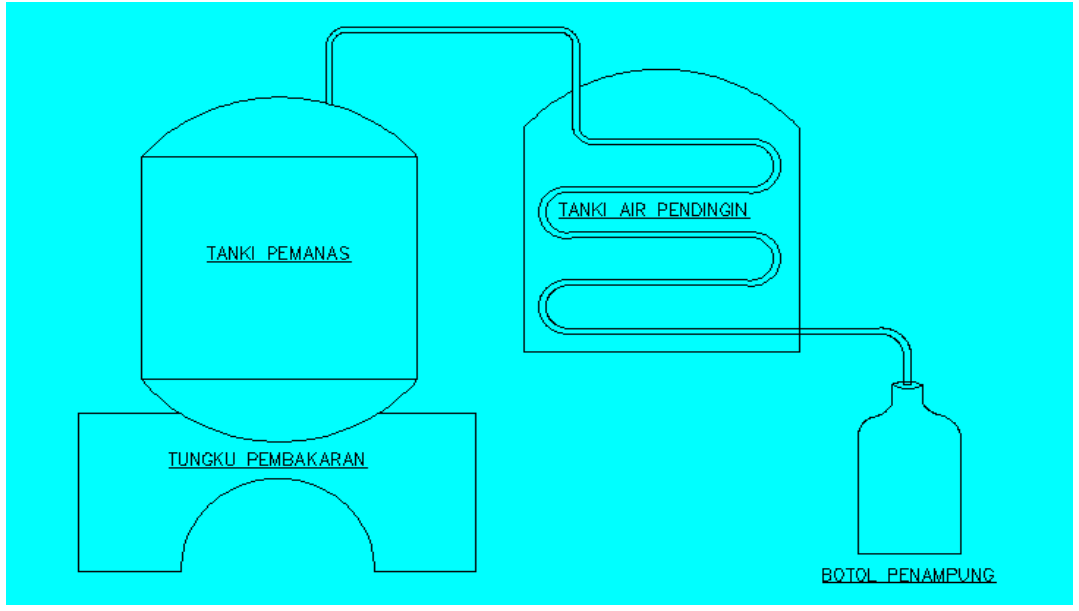

Gambar 4. Design Alat Pembuat Bioetanol (Hambali, 2008)

\section{Rancangan Logo Brand Be Kepo}

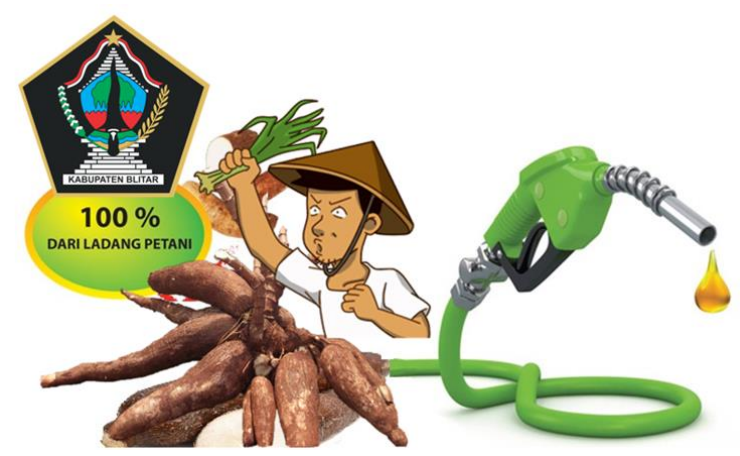

Gambar 5. Rancangan Logo Brand Be Kepo (Penulis, 2021)

\section{KESIMPULAN}

Dari uraian yang telah dipaparkan, dapat disimpulkan bahwa "Be KePo (Bioetanol Ketela Pohon): Alternatif Pengganti Bahan Bakar Minyak Fosil Sebagai Usaha Ekonomi Produktif Masyarakat Petani Kabupaten Blitar" merupakan sebuah ide inovatif di bidang energi dan pemberdayaan ekonomi masyarakat untuk menjawab dua masalah sekaligus yang saat ini dihadapi oleh masyarakat di Kabupaten Blitar. Masalah pertama yaitu ancaman kelangkaan sumber energi minyak bumi yang berasal dari fosil dan masalah kedua yaitu tingginya angka kemiskinan yang terjadi di wilayah Kabupaten Blitar. Dengan inovasi Be Kepo ini, masyarakat Kabupaten Blitar tidak perlu lagi khawatir akan kelangkaan bahan bakar minyak. Sebab bioetanol yang berasal dari ketela pohon ini, dapat menggantikan peran dan fungsi dari bahan bakar minyak yang memang sangat dibutuhkan oleh masyarakat modern saat ini. Selain itu, melalui inovasi Be Kepo ini, masyarakat miskin di Kabupaten Blitar terutama yang bekerja di sektor pertanian, bisa memiliki usaha dalam memproduksi bahan bakar minyak bioetanol.

Melalui inovasi Be Kepo ini, masyarakat miskin di Kabupaten Blitar khususnya yang saat ini bekerja di bidang pertanian tidak akan lagi menjual produk pertanian secara mentah. Namun mereka akan mengolahnya terlebih dahulu menjadi bioetanol yang siap untuk dikonsumsi sebagai bahan bakar alternatif pengganti bahan bakar minyak fosil. Bioetanol ini dapat dipastikan akan laris di pasaran baik di pasar lokal, nasional, maupun internasional. Hal ini dikarenakan masyarakat di seluruh dunia dapat dipastikan membutuhkan bahan bakar minyak sebagai penunjang kehidupan 
modern yang sarat akan penggunaan teknologi-teknologi modern untuk mempermudah dan mempercepat berbagai aktivitasnya. Teknologi-teknologi modern tersebut tentunya membutuhkan energi sebagai sumber penggerak, dan salah satu sumber energi yang sering digunakan adalah bahan bakar minyak. Bahan bakar minyak bioetanol yang berasal dari bahan nabati, tentu saja akan sangat diminati oleh masyarakat dunia karena ramah lingkungan dan tidak akan habis sebab berasal dari SDA yang dapat diperbaharui. Dengan usaha ekonomi produktif yang dilakukan oleh masyarakat petani di Kabupaten Blitar ini, tentu saja akan meningkatkan kondisi ekonomi keluarga petani sebagai pelaku usaha Be Kepo. Harapannya masyarakat di Kabupaten Blitar yang saat ini berada di bawah garis kemiskinan, akan berdaya dan akan terlepas dari belenggu kemiskinan.

\section{DAFTAR PUSTAKA}

Amilyaayu. (2011, April 12). Bab II: Gambaran Umum BPS Kabupaten Blitar. Retrieved from Academia.edu: https://www.academia.edu/8898614/BAB || Gambaran Umum BPS Kab Blitar

Arif, S. (2012, Oktober 2). Warga Miskin di Blitar Meningkat 70 Ribu Jiwa. Retrieved from Sindonews.com: https://daerah.sindonews.com/berita/676118/23/warga-miskin-di-blitarmeningkat-70-ribu-jiwa

Azhar, K. A. (2016, April 25). Transportasi Darat. Retrieved from Biro Penerbit KMTS FT UGM: http://www.bptsugm.com/2016/04/transportasi-darat.html

BPS Kab. Blitar \& Bapeda Kab. Blitar. (2018). Kabupaten Blitar dalam Angka 2018. Blitar: Badan Pusat Statistik Kabupaten Blitar.

BPS Kabupaten Blitar. (2020). Kabupaten Blitar Dalam Angka 2020. Blitar: Badan Pusat Statistik Kabupaten Blitar.

Frastuti, M., \& Royda. (2020). Faktor Ekonomi yang Mempengaruhi Minat Konsumen Untuk Menggunakan Sistem Pembangkit Listrik Tenaga Surya (PLTS) Atap di Kota Palembang. BISEI: Jurnal Bisnis dan Ekonomi Islam, V(2), 49-60.

Habib, M. A. (2015). Pergeseran Nilai dan Dukungan Sosial Keluarga Pada Orang Tua Lanjut Usia (Studi Kasus Pada Lansia Miskin di Kabupaten Blitar). Komunitas, IV(2), 1-10.

Habib, M. A. (2021). Kajian Teoritis Pemberdayaan Masyarakat dan Ekonomi Kreatif. Ar Rehla: Journal of Islamic Tourism, Halal Food, Islamic Traveling, and Creative Economy, I(2), 106134. Retrieved from https://doi.org/10.21274/ar-rehla.v1i2.4778

Hambali, E. (2008). Teknologi Bioenergi. Jakarta: PT. Agromedia Pustaka.

Hudaya, T. (2016). Potensi, Pengalolaan, dan Teknologi Pemanfaatan Biomassa serta Llstrik Terbarukan untuk Ketahanan Energi Indonesia di Masa Depan. Bandung: Repository Universitas Katolik Parahyangan. Retrieved from http://repository.unpar.ac.id/bitstream/handle/123456789/365/ORASI Dies Natalis FTI\%2 02016 Tedi\%20Hudaya Potensi Pengelolaan dan Teknologip.pdf?sequence $=1$ \&isAllowed $=y$

Kuncahyo, P., Fathallah, A., \& Sanuri, S. (2013). Analisa Prediksi Potensi Bahan Baku Biodiesel Sebagai Suplemen Bahan Bakar Motor Diesel di Indoesia. Jurnal Teknik ITS, II(1), 62-66.

Mustanir, A., Ibrahim, M., Sapri, S., \& Razak, M. R. (2020). Participatory Rural Appraisal: Transect dan Matriks Budidaya Pertanian dalam Pemberdayaan Masyarakat Penyiapan Kebun Bibit Desa. JMM (Jurnal Masyarakat Mandiri), 703-713. 
Purnomo, B. C., Widiyanto, A., Munahar, S., Purwantini, A. H., Muliawanti, L., \& Rosyidi6, M. I. (2020). Implementasi Energi Biogas Sebagai Energi Alternatif Pembangkit Listrik di Kabupaten Boyolali. CARADDE: Jurnal Pengabdian Kepada Masyarakat, III(2), 219-228.

Safitri, E. (2013). Bioetanol dari Singkong. Samarinda: Slideshare. Retrieved from https://www.slideshare.net/ekafitryalone/makalah-bioetanol-dari-singkong

Soesilo, Y. H., \& Agus Suman, D. K. (2008). Penyebab Kemiskinan Masyarakat Tani (Studi di Dusun Ngebrong, Desa Tawangsari, Kecamatan Pujon, Kabupaten Malang). Journal of Indonesian Applied Economics, II(1), 57-67.

Suroso. (2015). Kilang Pengolahan BBM Dioptimalkan. Harian Pagi Jawa Pos.

Wiratmaja, I. G., \& Elisa, E. (2020). Kajian Peluang Pemanfaatan Bioetanol Sebagai Bahan Bakar Utama Kendaraan Masa Depan di Indonesia. Jurnal Pendidikan Teknik Mesin Undiksha, VIII(1), 1-8.

Yakinudin, A. (2016). Bioetanol Singkong Sebagai Sumber Bahan Bakar Terbaharukan dan Solusi Untuk Meningkatkan Penghasilan Petani Singkong. Bogor: Repository Institut Pertanian Bogor. Retrieved from http://ipb.ac.id/lombaartikel/pendaftaran/uploads/s1/teknologi-danenergi/artikel ilmiah bioetanol.pdf 